\title{
Pathogens associated with persistent diarrhoea in children in low and middle income countries: systematic review Katharine Abba*1, Rebecca Sinfield ${ }^{2}$, C Anthony Hart and Paul Garner ${ }^{1}$
}

Address: ${ }^{1}$ International Health, Liverpool School of Tropical Medicine, Pembroke Place, Liverpool, L3 5QA, UK and ${ }^{2}$ Arrowe Park Hospital, Arrowe Park Road, Upton, Wirral, Merseyside, CH49 5PE, UK

Email: Katharine Abba* - k.abba@liverpool.ac.uk; Rebecca Sinfield - Becca.sinfield@talk21.com; C Anthony Hart - K.Abba@liv.ac.uk; Paul Garner - pgarner@liverpool.ac.uk

* Corresponding author

Published: 10 June 2009

BMC Infectious Diseases 2009, 9:88 doi:10.1 186/147|-2334-9-88

This article is available from: http://www.biomedcentral.com/I47/-2334/9/88

(C) 2009 Abba et al; licensee BioMed Central Ltd.

This is an Open Access article distributed under the terms of the Creative Commons Attribution License (http://creativecommons.org/licenses/by/2.0), which permits unrestricted use, distribution, and reproduction in any medium, provided the original work is properly cited.
Received: 31 October 2008

Accepted: 10 June 2009

\begin{abstract}
Background: Persistent diarrhoea in children is a common problem in low and middle income countries. To help target appropriate treatment for specific pathogens in the absence of diagnostic tests, we systematically reviewed pathogens most commonly associated with persistent diarrhoea in children.

Methods: We sought all descriptive studies of pathogens in the stool of children with diarrhoea of over 14 days duration in low and middle income countries with a comprehensive search of the MEDLINE, EMBASE, LILACS and WEB OF SCIENCE databases. We described the study designs and populations, assessed the quality of the laboratory tests, and extracted and summarised data on pathogens. For Escherichia coli, we calculated high and low prevalence estimates of all enteropathic types combined. Results across studies were compared for geographical patterns.

Results: Nineteen studies were included. Some used episodes of diarrhoea as the unit of analysis, others used children. The quality of reporting of laboratory procedures varied, and pathogens (particularly $E$. coli types) were classified in different ways. As there were no apparent regional differences in pathogen prevalence, we aggregated data between studies to give a guide to overall prevalence. Enteropathic $E$. coli types were commonly found in children with persistent diarrhoea (up to $63 \%$ ). Various other organisms, including viruses, bacteria and parasites, were detected but across all studies their prevalence was under $10 \%$. However, these pathogens were also found in similar frequencies in children without diarrhoea.

Conclusion: A number of pathogens are commonly associated with persistent diarrhoea in children, but in children without diarrhoea the pathogens are found with similar frequencies. New research with carefully selected controls and standardised laboratory investigations across countries will help map causes and help explore effective options for presumptive treatment.
\end{abstract}




\section{Background \\ The problem}

In 2002, diarrhoea caused an estimated $13.2 \%$ of child deaths worldwide[1], most of them in children under the age of five in low and middle income countries[2]. In this group of children, around 3\% to $19 \%$ of acute diarrhoea episodes become persistent[3], and some experts estimate that up to $50 \%$ of diarrhoea deaths may be due to persistent diarrhoea[1]. As the number of deaths from acute diarrhoea reduces following the widespread use of oral rehydration therapy, the contribution of persistent diarrhoea to overall diarrhoea mortality is increasing. In addition, persistent diarrhoea may adversely affect nutritional status[4] and is often associated with malnutrition.

Children living in poor areas with poor hygiene and sanitation conditions and children with poor nutritional status are most at risk of developing persistent diarrhoea[3]. As poor nutrition is both a risk factor and a consequence of persistent diarrhoea, the two are very commonly associated. Children with HIV/AIDS are at particular risk; at initial presentation to hospital with HIV/AIDS, around 36-50\% [5-7] of children have persistent diarrhoea. Dysentery and more severe diarrhoeal illnesses are more likely to become persistent than milder episodes[3]. Previous antibiotic use and irrational use of antibiotics are also considered to be risks factors for persistent diarrhoea[3].

\section{Definition and causes}

The World Health Organization (WHO) defines diarrhoea as the passing of three or more loose stools (which take the shape of the container) within a 24 hour period. A new episode of diarrhoea can occur after two full days without diarrhoea. Episodes of diarrhoea lasting for less than 14 days are defined as acute, episodes lasting for more than 14 days are defined as persistent.

The causes of persistent diarrhoea in populations are poorly understood, and in individuals often unknown. Some pathogens, such as Cryptosporidium, Giardia lamblia and enteroaggregative Escherichia coli (EAggEC) are thought to be associated with persistent diarrhoea in some locations[3]. Children with persistent diarrhoea and HIV infection may have different patterns of enteric pathogens than those without HIV[8]. Pathogens detected in persistent diarrhoea are often not the same as those detected in the original acute episode, suggesting that secondary infections may be important[9]. In addition, children may be infected with more than one enteric pathogen, making it difficult to identify which, if any, is causing the illness, or may have no detectable enteric pathogens. Persistent diarrhoea may also be associated with bacterial overgrowth in the small bowel[10], and with poor nutritional status[11]. In addition, the diarrhoea may be caused by multiple factors including micro- nutrient deficiencies, milk or food intolerances, or diseases of the bowel, as well as prior antibiotic therapy[12].

\section{When and how to treat}

The current recommendations of the Integrated Management of Childhood Illness programme[13] for treating persistent diarrhoea is that children with bloody diarrhoea are treated with antibiotics for Shigella, or for Entamoeba histolytica where the organism is detected in the stool; it is recommended that children with watery diarrhoea are not treated with antimicrobials; except where Giardia lamblia is found.

Even when an enteric pathogen is detected in children with persistent diarrhoea, it is not always clear that this is the cause of the illness. In addition, health workers in low and middle income countries often have limited access to diagnostic facilities to analyse stool samples of children with diarrhoea. In these situations, treatment needs to be syndromic, based on symptoms and the most likely cause of the symptoms; and may include replacement fluid and electrolytes, nutritional rehabilitation and sometimes drug treatment[12].

The use of antimicrobials presumptively needs to be approached with caution, as this can lead to drug resistance, and also to potential adverse reactions with some micro-organisms: entero-haemorrhagic E. coli (EHEC) may release toxins more readily when a person is treated with certain types of antibiotic, potentially causing severe illness[14].

Given the limited knowledge about the causes of persistent diarrhoea, we carried out a systematic review of studies that have attempted to identify aetiological agents in young children with this condition in low and middle income countries. We hoped in particular to identify whether any particular organisms were commonly associated with this condition, and if there were any geographic patterns. Either could help guide treatment of this condition in the absence of diagnostic facilities. The objective of this review was to summarise studies of pathogens reported in children with persistent diarrhoea and, where available, in appropriate comparison groups without diarrhoea; and to explore whether there are any patterns in the findings by region.

\section{Methods \\ Inclusion criteria}

We searched for published descriptive studies that analysed routinely collected data, data collected as part of a surveillance project or point survey data, and which provided data on pathogens detected in the stool of at least 30 children under the age of six years, living in a low or mid- 
dle income country and having persistent diarrhoea (over 14 days duration). In reports where the age range of participants was not specifically stated, but it was apparent that all or almost all participants were below the age of six, these studies were included. Participants could be recruited from any setting including the general community, primary health care services, and hospital outpatient and inpatient services. Studies could also include an appropriate comparison group of children without diarrhoea.

Studies also including older children or adults, or diarrhoea lasting for less than 14 days, were included provided that data from observations specific to children under the age of six with persistent diarrhoea could be extracted. Studies presenting data on only one species of pathogen were excluded.

\section{Search strategy}

The search strategy was developed in collaboration with an information retrieval specialist (see below). The strategy was amended where necessary to search the other databases listed. No language restrictions were applied. The reference lists of included studies were also scrutinised for additional relevant studies, and an informal search was undertaken of 'Google Scholar' using the search terms 'pathogens persistent diarrhoea'. The final formal search was undertaken May 20, 2008.

\section{Search strategy}

Databases searched:

MEDLINE (1966 to date) via the OVID interface

EMBASE (1980 to date) via the OVID interface

LILACS database - Latin American and Caribbean Health Sciences Literature (1982 to present) - via Virtual Health Library interface

WEB OF SCIENCE (Science Citation Index Expanded 1945 to present)

The following search strategy was used in MEDLINE:

1. persistent (diarrhoea OR diarrhea) ti, ab.

2. chronic (diarrhoea OR diarrhea) ti, ab.

3. watery (diarrhea OR diarrhea) ti, ab

4. (diarrheal disease ${ }^{*}$ ) OR (diarrhoeal disease* ${ }^{*}$ ti, ab

6. 1 OR 2 OR 3 OR 4) NOT cancer NOT (inflammatory bowel disease* ${ }^{*}$ NOT (ulcerative colitis)
7. diarrhea, Infantile/classification OR diarrhea, infantile/ etiology OR diarrhea, infantile/microbiology OR diarrhea, infantile/parasitology OR diarrhea, infantile/ pathology [MeSH]

\section{6 OR 7 \\ 9. child* OR infant* OR pediatr* ti, ab}

\section{8 AND 9}

11. case-control studies [MeSH] OR epidemiological studies [MeSH]

12. descript* OR surve* OR monitor* ${ }^{*} \mathrm{i}, \mathrm{ab}$

\section{11 OR 12}

\section{10 AND 13, Limits:humans}

\section{Study selection}

Two authors independently inspected titles and abstracts identified by the literature search in order to identify potentially relevant publications. All potentially relevant publications identified by at least one reviewer were obtained in full text format, with the exception, due to time constraints, of reports not available within the United Kingdom. One author then applied the inclusion criteria to select which studies to include in the review, consulting with another in cases of uncertainty. All publications were scrutinised for duplication of study results.

\section{Data extraction}

For each study report, two authors worked together to extract information describing the characteristics of the study and assess its quality, using a proforma as a guide. The data items extracted are shown below.

\section{Data extracted from included studies}

Geographic location of the study, including relevant socio-economic or environmental situation, and WHO region

\section{Start and end dates of the study, and duration}

Age range of the participants, and any additional inclusion criteria or local factors such as HIV infection or malnutrition. Where the participants were recruited from, for example, outpatient clinic, hospital ward, community, and how they were sampled

Whether or not the study also had a comparison group without diarrhoea, how this group were selected and whether and how they were matched to the diarrhoea group 
Sample sizes of the persistent diarrhoea group and comparison group with no diarrhoea

Unit of analysis; whether data was presented by children or episodes

Types of enteric pathogen tested for in each group (persistent diarrhoea and comparison group without diarrhoea)*

Number of children (or episodes) tested for each pathogen*

Number or percentage of children, episodes or samples where each pathogen was detected*

Number or percentage of children, episodes or samples with any detected enteric pathogen*

* One author extracted this data.

We extracted data on selected pathogens only, which we identified as important potential causes of diarrhoea in terms of both prevalence and potential to cause disease. The list of pathogens for which we intended to extracted data, where available, is shown in Table 1 . We extracted, where available, data on 'any pathogen' only where studies tested for a reasonably comprehensive range of pathogens. Where any organisms presented in a study paper were excluded from our analysis, we did not use data presented on 'any pathogen' from that study.

For E. coli, we combined all enteropathic types (any which have the capacity to cause enteric illnesses), with the exception of the entero-haemorrhagic type (EHEC), into one category, because different studies classified E. coli very diversely, making it impossible to compare types across studies. E. coli of an unspecified type, or classed as 'untypable' was excluded from the analysis because it was not possible to assess whether it was enteropathic. E. coli described by the authors as diff. E. coli, EAEC-D, EAEC (diffuse) or E. coli showing diffuse Hep-2 adherence were also excluded due to uncertainty about whether or not they are pathogenic. EHEC was kept separate where possible due to its different behaviour when exposed to antibi- otic drugs. For each study a note was made of the E. coli types tested for, as described in the study.

Where it was not clear in a report whether some individuals may have tested positive for more than one type of $E$. coli, we calculated high and low estimates of overall enteropathic E. coli frequency, using the largest E. coli category as a conservative estimate and all $E$. coli categories added together as a high estimate, adjusted where appropriate using any additional information presented in the report (for example, number of participants with any pathogens detected, number with more than one pathogen detected).

We planned to also extract data for any subgroups presented in the reports (for example by age or HIV status), but no reports presented data for subgroups.

One author also extracted data to describe the quality of reporting of the laboratory procedures used for the study, and whether any of the pathogens were tested for antimicrobial sensitivity. The data items extracted are shown in Table 2.

\section{Data analysis}

For each relevant reported pathogen in each study, we extracted or calculated the number and percentage of children, in both the persistent diarrhoea group and comparison group without diarrhoea, with the pathogen detected in the stool, based on the number of cases or individuals tested and the number found positive. We also calculated the standard deviation and the 95\% confidence intervals around the percentage.

Studies were grouped by the WHO Region of the study population. For each region, and for all the studies together, we noted or calculated the following parameters for each pathogen and for any pathogen in combined groups with persistent diarrhoea:

Number of studies where the pathogen was tested for and results presented

Total number of participants or episodes where the pathogen was tested for and results presented

Table I: List of pathogens for which data was extracted

\begin{tabular}{lll}
\hline Viruses & Bacteria & Parasites \\
\hline Rotavirus & Campylobacter & Giardia lamblia \\
Enteric adenovirus & Shigella & Crytosporidium \\
Astrovirus & Salmonella & Entamoeba histolytica \\
Norovirus & Vibrio cholera & Microsporidia \\
& Enteropathic E coli (excluding EHEC) & Isospora \\
& Entero haemorrhagic E. coli (EHEC) & Cyclospora
\end{tabular}


Table 2: Assessment of laboratory procedures

\begin{tabular}{ll}
\hline Laboratory processes: & $\begin{array}{l}\text { Samples: Were there any methods or timings described for collecting, storing and transporting stool } \\
\text { samples? } \\
\text { Parasite detection: Were any methods described or referenced for the detection of parasites, other than } \\
\text { the word 'microscopy'? (e.g. stain, magnification)? } \\
\text { Bacterial Culture: Were any methods described or referenced for the culture of bacteria, other than the } \\
\text { word 'culture'? (e.g. media, temperature) } \\
\text { Bacteria identification: Were any methods described or referenced for the identification of cultured } \\
\text { bacteria? } \\
\text { Virus detection: Were any methods described for the identification of viruses? } \\
\text { (the name of the test was sufficient) }\end{array}$ \\
\hline Quality control & $\begin{array}{l}\text { Were methods described for testing and controlling the quality of the laboratory tests used in the study? } \\
\text { Antimicrobial susceptibility testing }\end{array}$ \\
\hline Which of the pathogens detected in the study, if any, were tested for antimicrobial susceptibility?
\end{tabular}

The maximum and minimum percentage across studies of children or episodes where the pathogen was detected

The median percentage across studies of children or episodes where the pathogen was detected

Mean percentage across studies (weighted by study sample size) of children or episodes where each pathogen was detected

For the comparison groups without diarrhoea we calculated similar summary statistics. However, in order to make the mean percentage across the studies comparable with that for the persistent diarrhoea group, we weighted the contribution of each study according to the size of the group with persistent diarrhoea, rather than the group without diarrhoea. We did not calculate confidence intervals for statistics derived from combined studies.

We do not present any data based on a combined number of diarrhoea cases or comparisons of less than 30 .

\section{Results \\ Selection of studies}

The initial search returned 1,853 references, from which we selected 102 for full text retrieval; of these we were able to retrieve 98; four were not available within the United

Table 3: Reasons for exclusion of reports identified in the initial screening process as potentially relevant

\begin{tabular}{lc}
\hline Reason for exclusion & Number of Reports \\
\hline Diarrhoea status of participants & 9 \\
\hline Included children with acute diarrhoea only & 2 \\
Wrong definition of persistent diarrhoea & 1 \\
Asymptomatic children only & 2 \\
Included all children in a community, whether or not they had diarrhoea & 41 \\
No separate analysis for cases of acute and persistent diarrhoea &
\end{tabular}

Other participant characteristics

Study design factors

Less than 30 participants

Faecal samples taken in the acute stage (before day 14) of the persistent episode

Tested for one organism only

Sampled only children who had been in close contact with Shigella dysentery

Reviewed hospital records only for children found positive for enteric pathogens

5

5

4

I

I

\section{Not relevant}


Kingdom and were therefore not included due to lack of time and resources. From these 98 reports we selected 14 studies for inclusion in the review. Table 3 lists the reasons for exclusions of reports not included, and the number in each category. We found reports of a further three relevant studies through the reference lists of included studies, another two through a different search undertaken for another, related review, and three through an informal search of 'Google Scholar'. We included a total of 20 reports describing 19 studies[4,15-33]. Two reports were from the same surveillance project but presented data on different pathogens[15,16], and also included children of a slightly different age range.

\section{Characteristics of included studies}

Details of the characteristics of the individual studies included in the review are presented in Tables 4 and 5 (link). Table 4 shows the characteristics of all the included studies, in terms of the groups with persistent diarrhoea, and Table 5 shows only the eight studies with a comparison group without diarrhoea[4,17-20,23,27,28,30], in terms of the comparison group. One paper[32] did present findings for a comparison group, but this group was excluded from the analysis because it only included 15 individuals. Two papers based on the same data set are described separately as they present data on a slightly different age group $[15,16]$. Within each table, the studies are arranged by WHO region where they were carried out. Each study is named according to the country where it was conducted and the year of publication. A summary of the information presented in Tables 4 and 5 is presented below.

\section{Locations and settings}

Ten studies were conducted in the South-East Asia region; four in Bangladesh[15-18,32] and six in India [19-24]. Five were conducted in the Americas, including three in Brazil[4,27,30], one in Guatemala[28] and one in Mexico[29]. Two were conducted in the Western Pacific region, one on the border between Thailand and Cambodia[25], and one in Vietnam[26]. Two studies were conducted in the African region, both in Zambia[31,33].

Some studies were conducted within particularly vulnerable communities, including three in areas described as urban slums or shantytowns $[4,23,27]$, one in a rural indigenous community[28] and one in a resettlement camp for refugees[25].

\section{Participants}

The included studies all involved between 40 and 410 children with persistent diarrhoea; 11 studies had less than 100 participants $[4,19,20,24-30,33]$, seven had more than 100 but less than 200 participants $[17,18,21$ -
23,31,32], and one had more than 200 participants $[15,16]$.

Fourteen studies included children from birth to a specific age; in one study it was two years[19], in six it was three years $[20,22,23,28,30]$, in one it was four years[4], in five it was five years[15-17,21,25,27] and in one it was six years[18]. Others included children aged one to 36 months[16], three to 24 months[32] one to five years[24], and 15 months to five years[33]. Two did not state an age range for inclusion, but presented the mean and median participant ages, respectively 16.6 months[29], and 18 months[31]. There were no apparent patterns of age range inclusion by region.

Five studies [19,20,28,31,32] (three in Southeast Asia, one in the Americas, one in the African region) excluded children with bloody diarrhoea, or included only those with watery diarrhoea. Three included children with all types of persistent diarrhoea, while the other studies did not describe the type of diarrhoea included. One study in the African region included only children with diarrhoea over 30 days in duration[33], one in the Americas excluded those with diarrhoea that had persisted for longer than 18 days[28].

Five studies included only children with additional signs and symptoms; two in Southeast Asia stated that the children must have lost weight or failed to gain weight during the episode $[19,24]$, two (one in Southeast Asia, one in Africa) that the children should have specific signs of under nutrition [20,31], one in the Western Pacific specified that children should also have either a rectal temperature of over $38^{\circ} \mathrm{C}$, colic or vomiting[25]. One study in the Americas excluded children with specific diagnoses such as caeliacs disease or short bowel syndrome[29], one in South East Asia excluded children with systemic infections[32] and another in Africa excluded children with neurological diseases[31]. Two studies excluded children who had recently received antibiotics $[30,32]$.

Two studies; both from Africa, looked specifically at children who were HIV positive, and presented data on HIV positive and HIV negative individuals separately. The data is not presented separately in this review, as in one study only 24 individuals were HIV positive[33] and the other reported no significant differences in pathogen frequency between the HV positive and HIV negative groups[31].

\section{Sources of participants}

Six of the included studies employed active surveillance to identify all cases of persistent diarrhoea within a specific cohort of children in a defined community, including three from South-East Asia[17,18,23] and three from the 
Table 4: Characteristics of included studies: groups with persistent diarrhoea

\begin{tabular}{|c|c|c|c|c|c|c|c|}
\hline Study report & Location & Start Duration & Participants & Source of cases & $\begin{array}{l}\text { Sampling } \\
\text { method }\end{array}$ & $\begin{array}{l}\text { Number of } \\
\text { cases }\end{array}$ & Unit of Analysis \\
\hline $\begin{array}{l}\text { Bangladesh } \\
\text { 1992a [16] }\end{array}$ & Matlab (rural) & $\begin{array}{l}1988 \\
1 \mathrm{yr}\end{array}$ & $<5$ yrs & $\begin{array}{l}\text { Active } \\
\text { household } \\
\text { surveillance }\end{array}$ & $\begin{array}{l}\text { All cases } \\
\text { identified }\end{array}$ & $\begin{array}{l}\text { Varied by } \\
\text { pathogen } \\
(68-184)\end{array}$ & Episodes \\
\hline $\begin{array}{l}\text { Bangladesh } \\
\text { I992b [17] }\end{array}$ & Mirzapur (rural) & $\begin{array}{l}1987 \\
2 \text { yrs }\end{array}$ & $<6$ yrs & $\begin{array}{l}\text { Active } \\
\text { household } \\
\text { surveillance }\end{array}$ & $\begin{array}{l}\text { All cases } \\
\text { identified }\end{array}$ & $\begin{array}{l}\text { Varied by } \\
\text { pathogen } \\
(53-153)\end{array}$ & Episodes \\
\hline India 1989 [18] & New Delhi & $\begin{array}{l}1984 \\
1 \mathrm{yr}\end{array}$ & $\begin{array}{l}<2 \text { yrs, no blood } \\
\text { in stool, weight } \\
\text { loss }\end{array}$ & $\begin{array}{l}\text { Hospital } \\
\text { admissions }\end{array}$ & $\begin{array}{l}\text { Consecutive } \\
\text { cases }\end{array}$ & 92 & Children \\
\hline India 1992 [19] & New Delhi & $\begin{array}{l}1988 \\
28 \mathrm{mths}\end{array}$ & $\begin{array}{l}<3 \text { yrs, no blood } \\
\text { in stool, weight } \\
\text { for height }=90 \% \\
\text { of standard }\end{array}$ & $\begin{array}{l}\text { Hospital } \\
\text { admissions }\end{array}$ & Not described & 81 & Children \\
\hline India 1999 [22] & Slum New Delhi & $\begin{array}{l}\text { Unclear } \\
\text { Unclear }\end{array}$ & $<3$ yrs & $\begin{array}{l}\text { Active } \\
\text { household } \\
\text { surveillance }\end{array}$ & $\begin{array}{l}\text { All cases } \\
\text { identified }\end{array}$ & 115 & Episodes \\
\hline Brazil 1990 [26] & $\begin{array}{l}\text { Urban slum, } \\
\text { Fortaleza }\end{array}$ & $\begin{array}{l}1984 \\
28 \text { mths }\end{array}$ & $<5$ yrs & $\begin{array}{l}\text { Active } \\
\text { household } \\
\text { surveillance }\end{array}$ & $\begin{array}{l}\text { All cases } \\
\text { identified }\end{array}$ & 40 & Episodes \\
\hline Brazil I995 [29] & Fortaleza & $\begin{array}{l}1988 \\
32 \mathrm{mths}\end{array}$ & $\begin{array}{l}<3 \text { yrs, no } \\
\text { antibiotics in } \\
\text { past } 72 \text { hrs }\end{array}$ & $\begin{array}{l}\text { Hospital } \\
\text { admissions }\end{array}$ & Not described & 56 & Children \\
\hline Brazil 2000 [4] & $\begin{array}{l}\text { Shanty town } \\
\text { Fortaleza }\end{array}$ & $\begin{array}{l}1989 \\
45 \text { mths }\end{array}$ & $<4$ yrs & $\begin{array}{l}\text { Active } \\
\text { household } \\
\text { surveillance }\end{array}$ & $\begin{array}{l}\text { All cases } \\
\text { identified }\end{array}$ & 88 & Episodes \\
\hline $\begin{array}{l}\text { Bangladesh } \\
\text { I988 [14] }\end{array}$ & Dhaka & $\begin{array}{l}1983 \\
3 \text { yrs }\end{array}$ & $<5$ yrs & $\begin{array}{l}\text { Outpatient } \\
\text { attendances }\end{array}$ & $\begin{array}{l}\text { Systematic } \\
\text { every } 25^{\text {th }} \text { case }\end{array}$ & 410 & Children \\
\hline $\begin{array}{l}\text { Bangladesh } \\
1991 \text { [15] }\end{array}$ & Dhaka & $\begin{array}{l}1983 \\
3 \text { yrs }\end{array}$ & I mth to 3 yrs & $\begin{array}{l}\text { Outpatient } \\
\text { attendances }\end{array}$ & $\begin{array}{l}\text { Systematic } \\
\text { every } 25^{\text {th }} \text { case }\end{array}$ & $\begin{array}{l}\text { Varied by } \\
\text { pathogen } \\
(391-445)\end{array}$ & Children \\
\hline $\begin{array}{l}\text { Bangladesh } \\
\text { I998 [31] }\end{array}$ & Dhaka & $\begin{array}{l}\text { Unclear } \\
3 \text { yrs }\end{array}$ & $\begin{array}{l}3 \text { mths to } 2 \text { yrs, } \\
\text { no blood in } \\
\text { stools, no } \\
\text { antibiotics, anti- } \\
\text { diarrhoeals or } \\
\text { systemic } \\
\text { infection }\end{array}$ & $\begin{array}{l}\text { Outpatient } \\
\text { attendances }\end{array}$ & Not described & 138 & Children \\
\hline India 1995a [20] & Madras & $\begin{array}{l}\text { Unclear } \\
\text { Unclear }\end{array}$ & $<5$ yrs & $\begin{array}{l}\text { Hospital } \\
\text { admissions }\end{array}$ & Not described & 100 & Children \\
\hline $\begin{array}{l}\text { India 1995b } \\
{[21]}\end{array}$ & Amritsar & $\begin{array}{l}\text { Unclear } \\
\text { Unclear }\end{array}$ & $<3$ yrs & $\begin{array}{l}\text { Hospital } \\
\text { admissions }\end{array}$ & Not described & 150 & Children \\
\hline India 200I [23] & Varanasi & $\begin{array}{l}1998 \\
15 \mathrm{mths}\end{array}$ & $\begin{array}{l}\text { I to } 5 \text { yrs, } \\
\text { weight loss or } \\
\text { failure to gain } \\
\text { weight }\end{array}$ & $\begin{array}{l}\text { Hospital } \\
\text { admissions \& } \\
\text { outpatient } \\
\text { attendances }\end{array}$ & Randomly & 57 & Children \\
\hline $\begin{array}{l}\text { Guatemala } \\
1992[27]\end{array}$ & $\begin{array}{l}\text { Rural } \\
\text { indigenous } \\
\text { community }\end{array}$ & $\begin{array}{l}1988 \\
20 \text { mths }\end{array}$ & $\begin{array}{l}<3 \text { yrs, watery } \\
\text { diarrhoea for } 14 \\
\text { to } 18 \text { days }\end{array}$ & $\begin{array}{l}\text { Active } \\
\text { household } \\
\text { surveillance }\end{array}$ & $\begin{array}{l}\text { All cases } \\
\text { identified }\end{array}$ & 49 & Children \\
\hline $\begin{array}{l}\text { Mexico } 2003 \\
{[28]}\end{array}$ & Mexico City & $\begin{array}{l}1997 \\
\text { Unclear } \\
\text { (24-36 mths) }\end{array}$ & $\begin{array}{l}\text { mean age } 16.6 \\
\text { mths, no specific } \\
\text { diagnosis }\end{array}$ & $\begin{array}{l}\text { Hospital } \\
\text { admissions }\end{array}$ & Not described & 89 & Children \\
\hline $\begin{array}{l}\text { Cambodia } 1992 \\
\text { [24] }\end{array}$ & $\begin{array}{l}\text { Resettlement } \\
\text { camp, Thailand } \\
\text { Cambodia } \\
\text { border }\end{array}$ & $\begin{array}{l}1989 \\
6 \text { mths }\end{array}$ & $\begin{array}{l}<5 \text { yrs, with } \\
\text { temperature } \\
\text { over } 38^{\circ} \mathrm{C} \text {, colic } \\
\text { or vomiting }\end{array}$ & $\begin{array}{l}\text { Outpatient } \\
\text { attendances }\end{array}$ & $\begin{array}{l}\text { Consecutive } \\
\text { cases }\end{array}$ & 79 & Children \\
\hline $\begin{array}{l}\text { Vietnam } 1992 \\
{[25]}\end{array}$ & Hanoi & $\begin{array}{l}1988 \\
1 \mathrm{yr}\end{array}$ & $<3$ yrs & $\begin{array}{l}\text { Hospital } \\
\text { admissions }\end{array}$ & Not described & 83 & Children \\
\hline $\begin{array}{l}\text { Zambia } 1995 \\
\text { [32] }\end{array}$ & Lusaka & $\begin{array}{l}\text { Unclear } \\
9 \text { mths }\end{array}$ & $\begin{array}{l}15 \text { mths to } 5 \text { yrs; } \\
\text { diarrhoea for at } \\
\text { least } 30 \text { days }\end{array}$ & $\begin{array}{l}\text { Hospital } \\
\text { admissions }\end{array}$ & $\begin{array}{l}\text { Consecutive } \\
\text { cases every } \\
\text { alternate day }\end{array}$ & 90 & Children \\
\hline $\begin{array}{l}\text { Zambia 200I } \\
\text { [30] }\end{array}$ & Lusaka & $\begin{array}{l}1998 \\
26 \text { mths }\end{array}$ & $\begin{array}{l}\text { Inpatient in } \\
\text { nutrition ward, } \\
\text { median } 18 \text { mths, } \\
\text { no blood in stool }\end{array}$ & $\begin{array}{l}\text { Hospital } \\
\text { admissions }\end{array}$ & $\begin{array}{l}\text { Consecutive } \\
\text { cases }\end{array}$ & 194 & Children \\
\hline
\end{tabular}


Americas $[4,27,28]$. Three sampled children attending hospital outpatient departments, including children who were also subsequently admitted to the wards, two in South-East Asia[15,16,32] and one in the Western Pacific[25]. Nine sampled only children who were already admitted to a hospital ward, four in South-East Asia [1922], two in the Americas[29,30], two in Africa[31,33] and one in the Western Pacific[26]. One study in South-East Asia included both inpatients and outpatients treated at a hospital[24].

\section{Sampling strategies}

All six of the community cohort studies included all the children identified with persistent diarrhoea over the duration of the project. Four of the studies recruiting patients at healthcare facilities also sampled all consecutive eligible patients $[19,25,31,33]$. One study included a random sample (method of randomisation not stated)[24] and one used a systematic sampling method (every $25^{\text {th }}$ patient) $[15,16]$. Reports of the remaining studies did not describe their sampling methods.

\section{Date of studies}

Most of the included studies were conducted over ten years ago, and none presented data collected after 2000. Taking the mid-year of the data collection period as the reference point, three collected data in 1985 or before $[15,16,19,27]$, eight collected data between 1986 and
$1990[4,17,18,20,25,26,28,30]$, and three collected data between 1996 and 1999 [24,29,31]. Five study reports $[21-23,32,33]$ did not state the date of the data collection, three were published 1995, one was published 1998, and one was published in 1999. There did not appear to be any pattern of date of study by WHO region.

\section{Duration of studies}

Most of the included studies collected data for a period of one year or more. One collected data for six months[25], and one over a period of nine months[33]. Six collected data for periods of whole years: three for one year $[17,19,26]$, one for two years [18] and two for three years $[15,16,32]$. Six collected data for other periods of time, between one and four years. Three study reports did not give any information about dates or durations of data collection [21-23]. There did not appear to be any pattern of duration of data collection period by WHO region.

\section{Units of analyses}

Five of the community cohort type studies used episodes as the unit of analysis, with children in both the persistent diarrhoea and comparison groups (where used) often included in the analysis more than once. One of the studies recruiting children from a community surveillance project was reporting baseline data for a clinical trial, and therefore included individual children only once[28]. The remaining studies presented data as for individual chil-

Table 5: Characteristics of included studies: comparison groups without diarrhoea

\begin{tabular}{|c|c|c|c|c|c|c|}
\hline Study report & Location & Source of cases & Number of cases & $\begin{array}{l}\text { Source of } \\
\text { comparison group } \\
\text { without diarrhoea }\end{array}$ & $\begin{array}{l}\text { Matching of } \\
\text { comparison group }\end{array}$ & $\begin{array}{l}\text { Number of } \\
\text { children without } \\
\text { diarrhoea }\end{array}$ \\
\hline $\begin{array}{l}\text { Bangladesh 1992a } \\
\text { [16] }\end{array}$ & Matlab (rural) & $\begin{array}{l}\text { Active household } \\
\text { surveillance }\end{array}$ & $\begin{array}{l}\text { Varied by } \\
\text { pathogen } \\
(68-184)\end{array}$ & $\begin{array}{l}\text { Same community } \\
\text { study cohort }\end{array}$ & $\begin{array}{l}\text { Age and proximity } \\
\text { of residence }\end{array}$ & $\begin{array}{l}\text { Varied by } \\
\text { pathogen } \\
(67-164)\end{array}$ \\
\hline $\begin{array}{l}\text { Bangladesh 1992b } \\
\text { [17] }\end{array}$ & Mirzapur (rural) & $\begin{array}{l}\text { Active household } \\
\text { surveillance }\end{array}$ & $\begin{array}{l}\text { Varied by } \\
\text { pathogen } \\
(53-153)\end{array}$ & $\begin{array}{l}\text { Same community } \\
\text { study cohort }\end{array}$ & $\begin{array}{l}\text { Age and proximity } \\
\text { of residence }\end{array}$ & $\begin{array}{l}\text { Varied by } \\
\text { pathogen } \\
(46-213)\end{array}$ \\
\hline India 1989 [18] & New Delhi & $\begin{array}{l}\text { Hospital } \\
\text { admissions }\end{array}$ & 92 & $\begin{array}{l}\text { Other wards with } \\
\text { non-gastro- } \\
\text { intestinal illnesses }\end{array}$ & $\begin{array}{l}\text { Age and } \\
\text { nutritional status }\end{array}$ & 92 \\
\hline India 1992 [19] & New Delhi & $\begin{array}{l}\text { Hospital } \\
\text { admissions }\end{array}$ & 81 & $\begin{array}{l}\text { Nutrition clinic } \\
\text { with failure to } \\
\text { thrive and weight } \\
\text { for height }=90 \% \\
\text { of standard }\end{array}$ & Not matched & 32 \\
\hline India 1999 [22] & Slum of New Delhi & $\begin{array}{l}\text { Active household } \\
\text { surveillance }\end{array}$ & 115 & $\begin{array}{l}\text { Same community } \\
\text { study cohort }\end{array}$ & $\begin{array}{l}\text { Age, nutritional } \\
\text { status and } \\
\text { proximity of } \\
\text { residence }\end{array}$ & 115 \\
\hline Brazil 1990 [26] & $\begin{array}{l}\text { Urban slum, } \\
\text { Fortaleza }\end{array}$ & $\begin{array}{l}\text { Active household } \\
\text { surveillance }\end{array}$ & 40 & $\begin{array}{l}\text { Same community } \\
\text { study cohort }\end{array}$ & Not matched & 38 \\
\hline Brazil I995 [29] & Fortaleza & $\begin{array}{l}\text { Hospital } \\
\text { admissions }\end{array}$ & 56 & $\begin{array}{l}\text { Children on other } \\
\text { wards }\end{array}$ & By age & 42 \\
\hline Brazil 2000 [4] & $\begin{array}{l}\text { Shanty town, } \\
\text { Fortaleza }\end{array}$ & $\begin{array}{l}\text { Active household } \\
\text { surveillance }\end{array}$ & 88 & $\begin{array}{l}\text { Same community } \\
\text { study cohort }\end{array}$ & By age and sex & 443 \\
\hline
\end{tabular}


dren, although none reported procedures to exclude children who presented to the facility more than once during the study period.

\section{Comparison groups without diarrhoea}

Eight study reports presented pathogen frequency data on an appropriate comparison group of children without diarrhoea, five in south-East Asia[17-20,23] and three in the Americas[4,27,30]. One study described a comparison group but did not present any relevant data[21]. In six studies, the comparison participants were matched to participants with persistent diarrhoea using specific criteria $[4,17-19,23,30]$, in two the diarrhoea and comparison groups were not matched[20,27]. Five of the studies with comparison groups were community cohort studies that recruited the comparison group from the same community $[4,17,18,23,27]$. The other three studies were based at health facilities and used a comparison group of children attending or admitted to the hospital with illnesses other than diarrhoea.

\section{Quality of reporting for laboratory procedures}

Table 6 gives a summary of the assessed quality of reporting of the laboratory procedures used in the study, plus an indication of whether there was any mention of antimi- crobial susceptibility testing of bacteria being carried out, and whether quality control procedures were described. The quality of reporting varied widely across studies in all WHO regions, with one study describing none of the procedures[24], while two reported six out of seven $[18,25]$. Two trials tested only for parasites and used three out of the three possible procedures on our checklist $[23,33]$. Only two studies reported testing bacterial isolates for antimicrobial susceptibility $[18,24,25]$, and two described quality control procedures[23,33].

\section{Potential pathogen prevalence}

Table S1 in Additional file 1 (link) shows, for each study, the percentage of cases testing positive for different pathogens in the stool, and associated 95\% confidence limits, in children with persistent diarrhoea, and where available, children without diarrhoea. The estimated prevalence of each pathogen tended to be very imprecise, due to small sample sizes. For studies with comparison groups without diarrhoea, there was no significant difference in prevalence of any pathogen between the two groups.

Under Table S1 in Additional file 1 we list the E. coli types tested for in each study, using the category conventions stated by authors. All of the studies included ETEC, most

Table 6: Laboratory Procedures described or referenced in the included study reports

\begin{tabular}{|c|c|c|c|c|c|c|c|}
\hline & Samples & Parasite detection & Bacterial culture & $\begin{array}{l}\text { Bacterial } \\
\text { identification }\end{array}$ & Virus detection & Quality control & $\begin{array}{l}\text { Antimicrobial } \\
\text { susceptibility } \\
\text { testing }\end{array}$ \\
\hline $\begin{array}{l}\text { Bangladesh } 1988 \\
{[14]}\end{array}$ & $\mathrm{x}$ & $x$ & $x$ & $x$ & $\sqrt{ }$ & $x$ & $\mathrm{x}$ \\
\hline $\begin{array}{l}\text { Bangladesh 1991 } \\
\text { [15] }\end{array}$ & $\sqrt{ }$ & - & $\sqrt{ }$ & $\sqrt{ }$ & $\sqrt{ }$ & $x$ & $x$ \\
\hline $\begin{array}{l}\text { Bangladesh 1992a } \\
{[16]}\end{array}$ & $\sqrt{ }$ & $\sqrt{ }$ & $\sqrt{ }$ & $\sqrt{ }$ & - & $x$ & $x$ \\
\hline $\begin{array}{l}\text { Bangladesh 1992b } \\
{[17]}\end{array}$ & $\sqrt{ }$ & $\sqrt{ }$ & $\sqrt{ }$ & $\sqrt{ }$ & $\sqrt{ }$ & $x$ & $\sqrt{ }$ \\
\hline $\begin{array}{l}\text { Bangladesh } 1998 \\
{[31]}\end{array}$ & $\sqrt{ }$ & $\sqrt{ }$ & $\sqrt{ }$ & $\sqrt{ }$ & $\sqrt{ }$ & $x$ & $x$ \\
\hline India 1989 [18] & $\sqrt{ }$ & $\sqrt{ }$ & $\sqrt{ }$ & $\sqrt{ }$ & $\sqrt{ }$ & $x$ & $x$ \\
\hline India $1992[19]$ & $\sqrt{ }$ & $x$ & $\sqrt{ }$ & $\sqrt{ }$ & $x$ & $x$ & $x$ \\
\hline India 1995a [20] & $x$ & $x$ & $\sqrt{ }$ & $\sqrt{ }$ & - & $x$ & $x$ \\
\hline India 1995b [2I] & $\sqrt{ }$ & $\sqrt{ }$ & $\sqrt{ }$ & $\sqrt{ }$ & - & $x$ & $x$ \\
\hline India 1999 [22] & $\sqrt{ }$ & $\sqrt{ }$ & - & - & - & $\sqrt{ }$ & - \\
\hline India 200I [23] & $x$ & $x$ & $x$ & $x$ & - & $x$ & $x$ \\
\hline $\begin{array}{l}\text { Cambodia } 1992 \\
{[24]}\end{array}$ & $\sqrt{ }$ & $\sqrt{ }$ & $\sqrt{ }$ & $\sqrt{ }$ & $\sqrt{ }$ & $x$ & $\sqrt{ }$ \\
\hline Vietnam 1992 [25] & $x$ & $x$ & $x$ & $x$ & $\sqrt{ }$ & $x$ & $x$ \\
\hline Brazil I990 [26] & $\sqrt{ }$ & $\sqrt{ }$ & $\sqrt{ }$ & $\sqrt{ }$ & $\sqrt{ }$ & $x$ & $x$ \\
\hline Brazil I995 [27] & $\sqrt{ }$ & $\sqrt{ }$ & $\sqrt{ }$ & $\sqrt{ }$ & $\sqrt{ }$ & $x$ & $x$ \\
\hline Brazil 2000 [4] & $\sqrt{ }$ & $\sqrt{ }$ & $\sqrt{ }$ & $x$ & $\sqrt{ }$ & $x$ & $x$ \\
\hline $\begin{array}{l}\text { Guatemala } 1992 \\
\text { [29] }\end{array}$ & $\sqrt{ }$ & $\sqrt{ }$ & $\sqrt{ }$ & $\sqrt{ }$ & $\sqrt{ }$ & $x$ & $x$ \\
\hline Mexico 2003 [28] & $x$ & $\sqrt{ }$ & $\sqrt{ }$ & $\sqrt{ }$ & - & $x$ & $x$ \\
\hline Zambia 1995 [32] & $\sqrt{ }$ & $\sqrt{ }$ & - & - & - & $\sqrt{ }$ & - \\
\hline Zambia 200I [30] & $x$ & $\sqrt{ }$ & $x$ & $x$ & - & $x$ & $x$ \\
\hline
\end{tabular}


also included EPEC; others included AggEC or EIEC; two studies included EHEC. In two studies[17,20], it was uncertain whether one category of E. coli referred to EPEC or EHEC; in these cases it was assumed to be EPEC. No percentages were calculated for individual E. coli types as different naming conventions would have made comparison between studies impossible. Two different sets of $E$. coli estimates are presented: those based on the upper estimate of the range, and those based on the lower estimates. Only two studies tested for isospora[31,33] and two tested for enteric adenovirus[4,19]. One study tested for Norovirus [4] but was excluded from the analysis because the sample size was less than 30. No studies tested for Astrovirus or Cyclospora. Two studies tested specifically for EHEC and found no EHEC infections[4,19].

As the prevalence of individual organisms did not show extreme variations between studies, we combined the data across studies to provide an approximate indicator of prevalence across studies.

Study findings combined by WHO region are shown in Table S2 in Additional file 1. Table S2 in Additional file 1 shows the number of studies testing for each pathogen, the combined number of persistent diarrhoea cases tested, the weighted mean percentage across studies of cases testing positive, and the range between studies. There were no apparent differences by region, although there were some differences between studies, for example, rotavirus was detected in between $0 \%$ and $20 \%$ of children.

Figure 1 illustrates in chart form the weighted mean percentage across all studies of cases testing positive for each pathogen included in the review. It is apparent that the stool samples of children with persistent diarrhoea contained a range of pathogens. With the exception of enteropathic E. coli types, each pathogen was found in less than $10 \%$ of children across studies; in the case of E. coli the estimated range was between $25 \%$ and $33 \%$. In studies that tested for a reasonably comprehensive range of pathogens, $65 \%$ of cases had some kind of pathogen detected in the stool, varying widely between studies from $36 \%$ to $88 \%$.

For each pathogen in each region, a median percentage of cases testing positive across the studies was also calcu-

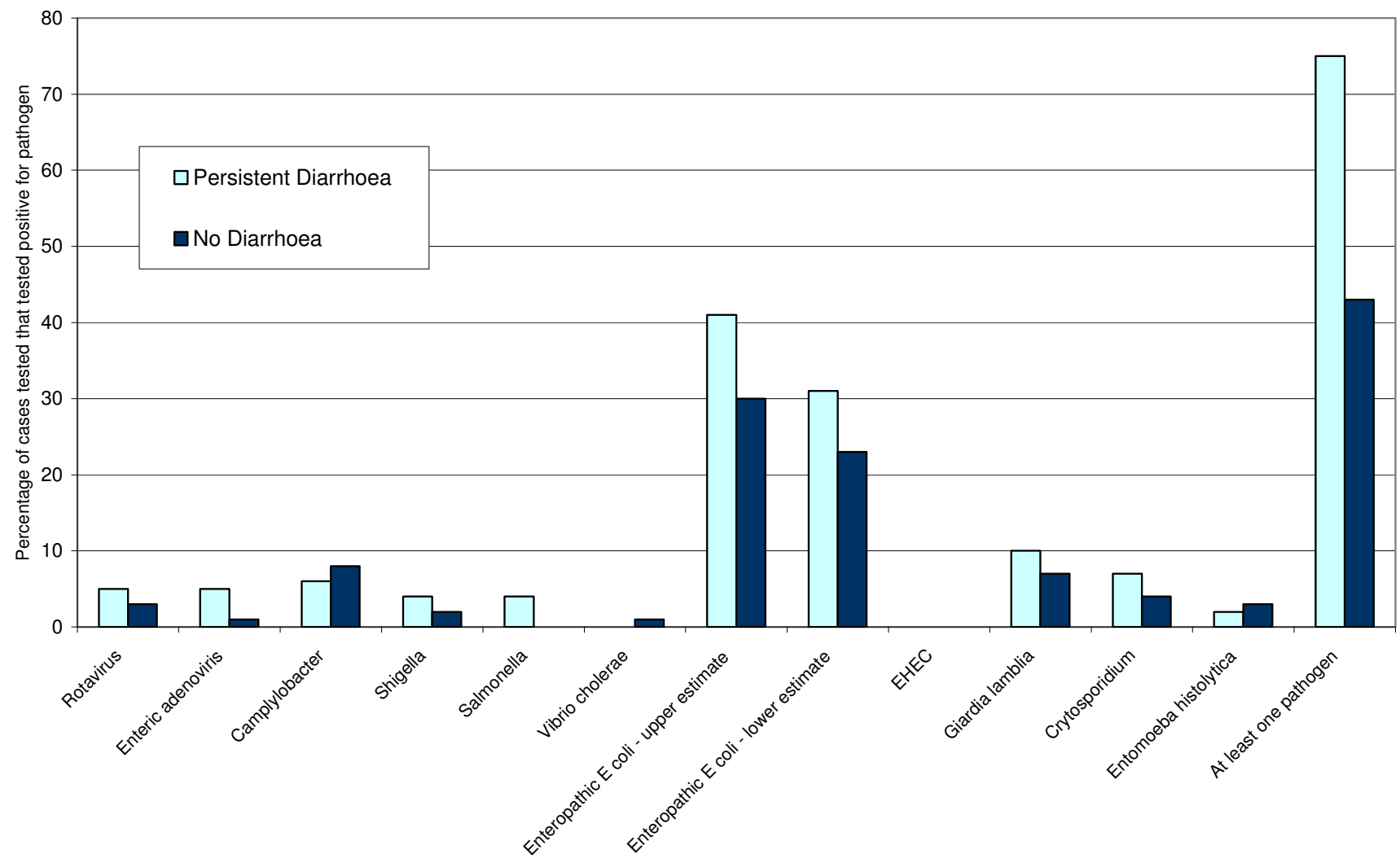

Figure I

Weighted mean percentage across all studies of cases testing positive for each pathogen included in the review. 
Table 7: Summary of studies with control group: number of participants testing positive for different pathogens by region

\begin{tabular}{|c|c|c|c|c|c|c|c|c|c|c|c|c|c|c|c|}
\hline & \multicolumn{5}{|c|}{ South-East Asia } & \multicolumn{5}{|c|}{ The Americas } & \multicolumn{5}{|l|}{ All } \\
\hline & \multirow{2}{*}{ Studies } & \multicolumn{2}{|c|}{ Persistent diarrhoea } & \multicolumn{2}{|c|}{ No diarrhoea } & \multirow{2}{*}{ Studies } & \multicolumn{2}{|c|}{ Persistent diarrhoea } & \multicolumn{2}{|c|}{ No diarrhoea } & \multirow{2}{*}{ Studies } & \multicolumn{2}{|c|}{ Persistent diarrhoea } & \multicolumn{2}{|c|}{ No Diarrhoea } \\
\hline & & $\mathrm{N}$ & $\begin{array}{l}\text { Weighted } \\
\text { Mean }\end{array}$ & $\mathrm{N}$ & $\begin{array}{l}\text { Weighted } \\
\text { Mean }\end{array}$ & & $\mathrm{N}$ & $\begin{array}{l}\text { Weighted } \\
\text { Mean }\end{array}$ & $\mathrm{N}$ & $\begin{array}{l}\text { Weighted } \\
\text { Mean }\end{array}$ & & $\mathrm{N}$ & $\begin{array}{l}\text { Weighted } \\
\text { Mean }\end{array}$ & $\mathrm{N}$ & $\begin{array}{l}\text { Weighted } \\
\text { Mean }\end{array}$ \\
\hline \multicolumn{16}{|l|}{ Viruses } \\
\hline Rotavirus & 4 & 496 & $2 \%$ & 501 & $1 \%$ & 3 & 162 & $12 \%$ & 162 & $7 \%$ & 7 & 658 & $5 \%$ & 663 & $3 \%$ \\
\hline $\begin{array}{l}\text { Enteric } \\
\text { adenovirus }\end{array}$ & 1 & 92 & $1 \%$ & 92 & $2 \%$ & 1 & 66 & $11 \%$ & 82 & $0 \%$ & 2 & 158 & $5 \%$ & 174 & $1 \%$ \\
\hline \multicolumn{16}{|l|}{ Bacteria } \\
\hline $\begin{array}{l}\text { Campylobac } \\
\text { ter }\end{array}$ & 4 & 489 & $8 \%$ & 375 & $9 \%$ & 2 & 96 & $0 \%$ & 80 & $0 \%$ & 6 & 585 & $6 \%$ & 455 & $8 \%$ \\
\hline Shigella & 4 & 496 & $5 \%$ & 501 & $3 \%$ & 3 & 184 & $3 \%$ & 520 & $2 \%$ & 7 & 680 & $4 \%$ & 1021 & $2 \%$ \\
\hline Salmonella & 3 & 326 & $6 \%$ & 337 & $0 \%$ & 3 & 184 & $0 \%$ & 520 & $0 \%$ & 6 & 510 & $4 \%$ & 857 & $0 \%$ \\
\hline $\begin{array}{l}\text { Vibrio } \\
\text { cholerae }\end{array}$ & 2 & 317 & $1 \%$ & 373 & $1 \%$ & 1 & 88 & $0 \%$ & 440 & $0 \%$ & 3 & 405 & $0 \%$ & 813 & $1 \%$ \\
\hline \multicolumn{16}{|l|}{$\begin{array}{l}\text { *All } \\
\text { Enteropathic }\end{array}$} \\
\hline $\begin{array}{l}\text { E coli - } \\
\text { upper } \\
\text { estimate }\end{array}$ & 4 & 386 & $32 \%$ & 329 & $27 \%$ & 3 & 164 & $63 \%$ & 75 & $38 \%$ & 7 & 550 & $41 \%$ & 604 & $30 \%$ \\
\hline \multicolumn{16}{|l|}{$\begin{array}{l}\text { *All } \\
\text { Enteropathic }\end{array}$} \\
\hline $\begin{array}{l}\text { E coli - } \\
\text { lower } \\
\text { estimate }\end{array}$ & 4 & 386 & $26 \%$ & 328 & $22 \%$ & 3 & 164 & $41 \%$ & 275 & $25 \%$ & 7 & 550 & $31 \%$ & 603 & $23 \%$ \\
\hline EHEC & 1 & 92 & $0 \%$ & 92 & $0 \%$ & 1 & 51 & $0 \%$ & 51 & $0 \%$ & 2 & 143 & $0 \%$ & 143 & $0 \%$ \\
\hline \multicolumn{16}{|l|}{ Parasites } \\
\hline $\begin{array}{l}\text { Giardia } \\
\text { lamblia }\end{array}$ & 5 & 504 & $8 \%$ & 540 & $7 \%$ & 3 & 184 & $14 \%$ & 522 & $7 \%$ & 8 & 688 & $10 \%$ & 1062 & $7 \%$ \\
\hline $\begin{array}{l}\text { Cryptospori } \\
\text { dium }\end{array}$ & 2 & 232 & $1 \%$ & 280 & $4 \%$ & 3 & 167 & $16 \%$ & 369 & $5 \%$ & 0 & 399 & $7 \%$ & 649 & $4 \%$ \\
\hline $\begin{array}{l}\text { Entamoeba } \\
\text { histolytica }\end{array}$ & 5 & 504 & $2 \%$ & 541 & $4 \%$ & 3 & 184 & $1 \%$ & 522 & $1 \%$ & 5 & 688 & $2 \%$ & 1063 & $3 \%$ \\
\hline $\begin{array}{l}\text { At least one } \\
\text { pathogen }\end{array}$ & 1 & 92 & $73 \%$ & 92 & $22 \%$ & 2 & 112 & $76 \%$ & 233 & $60 \%$ & 3 & 204 & $75 \%$ & 325 & $43 \%$ \\
\hline
\end{tabular}


lated. These are not presented, as in most cases they were less than 5\% (absolute difference) either side of the mean. The only exception was the lower estimate for $E$. coli in the Americas, where the mean was 35\% and the median was $25 \%$.

\section{Comparative prevalence of potential pathogens}

For studies with an appropriate comparison group, Table 7 shows the number of studies testing for each pathogen, total sample size, and weighted mean percentage across studies of cases and comparisons testing positive for each pathogen, separated by WHO region. There were no studies with a comparison group from the Western Pacific region.

Figure 2 illustrates in chart form the weighted mean percentages of cases tested that tested positive for different pathogens within the persistent diarrhoea groups and comparison groups without diarrhoea in all eight studies with a comparison group. As described in the methods section, the data from the comparison group in each study was weighted according to the sample size of the group with persistent diarrhoea.

It is apparent from Table 7 and Figure 2 that the frequency of detection of any kind of enteric pathogen was higher in children with persistent diarrhoea, but for individual pathogens any differences were very small (although differences between groups were larger in the Americas than in other locations).

\section{Discussion}

We were able to identify, retrieve and assess papers describing 19 studies, of which eight also presented data for an appropriate comparison group without diarrhoea. However, other relevant studies may have been published, but missed by the search. Some of the included studies had main purposes that were different from the

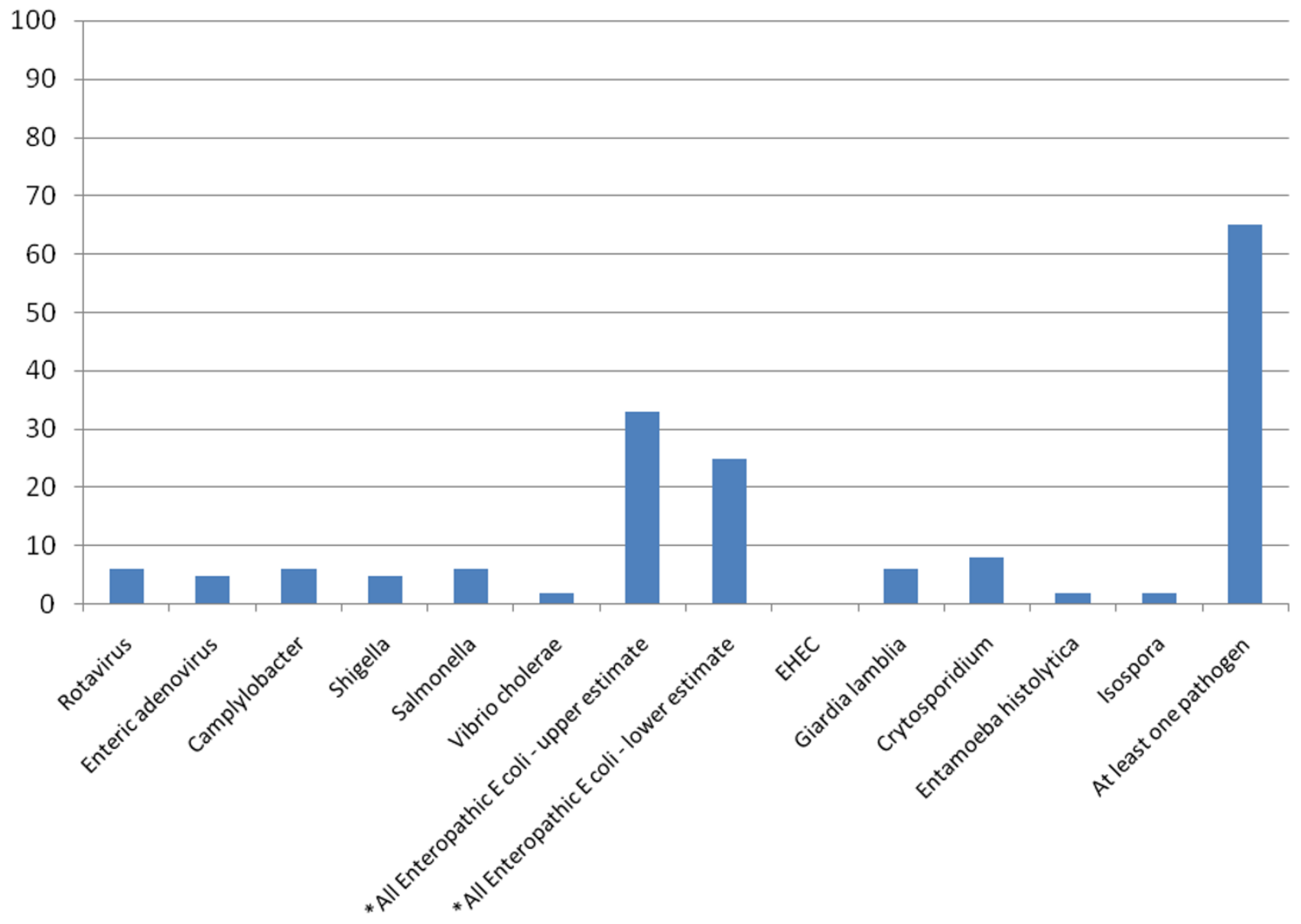

\section{Figure 2}

Weighted mean percentage of cases tested that tested positive for different pathogens in children with persistent diarrhoea and comparisons without diarrhoea. 
purpose of this review, and titles that reflected this, for example 'Endoscopic and histopathological evaluation of pre-school children with chronic diarrhoea' and 'Oral gentamicin is not effective treatment for persistent diarrhoea'. We identified two reports only through the search process for another review, and three through an informal search of 'Google Scholar'. We can therefore suppose that not all published studies presenting relevant data are indexed in such a way that even quite wide systematic electronic searches, such as the one we performed, can easily identify. In addition, we know of four studies that may possibly be relevant but that we were unable to obtain within the UK.

The included studies were conducted in a range of geographic locations, including South-East Asia, the Americas, Western Pacific and African Regions, some in contexts where children may have a particularly high risk for persistent diarrhoea, including slum areas and a resettlement camp for refugees. The two studies carried out in Africa were both based within the same hospital in Zambia; these were the only studies to specifically include children who were HIV positive; the sample sizes were too small to assess whether the patterns of enteric infection were different in HIV positive and HIV negative children.

The included studies used a range of methods and settings, including surveys of children attending clinics or admitted to hospital, baseline data collection on children recruited for a clinical trial and community surveillance projects seeking to actively identify children with persistent diarrhoea. The units of analyses also differed; some studies included individual children only once, while some included all separate cases, whether or not they were identified in the same child.

This review can only give an approximate indication of the actual frequency of different pathogens, for several reasons. Most studies had small sample sizes, so estimates from individual studies are imprecise, and different studies tested for different pathogens, therefore even when study results were combined, the sample size for some organisms was still small. Some of the pathogens that we considered to be important were not tested for in any of the studies. In the case of E. coli, evolving knowledge meant that different classification systems were used in different studies, making it impossible to combine data on type of E. coli across studies. Some studies included more types of $E$. coli than others, automatically leading to higher estimated prevalences for all enteropathic E. coli types combined. The reporting of microbiological procedures was generally poor, so it is unknown whether optimum testing methods were used. The majority of studies were more than ten years old; the relative prevalence of different pathogens in persistent diarrhoea may have changed since that time, and tests for different pathogens may have become more accurate. In addition, the duration of many studies was not a multiple of 12 months, so the results could have been affected by seasonal variations. In regards to the comparison groups without diarrhoea, in some studies the children may not have been typical of children without diarrhoea in the community, as they were hospital inpatients.

We used simple weighted means to combine data; this could have given undue weight to larger studies which may not have had findings typical of the other studies. However, we also calculated medians and found them very similar to the means, suggesting that any such effect, if present, was not large. We also combined data extracted from studies using different methodologies, including studies presenting data based on individuals and those presenting data on episodes, where some individuals were included more than once. This was a pragmatic decision based on the fact that in some studies it was unknown whether each case presented related to a different individual or not. The methodological difficulties may have been important if this review were to claim to represent a 'typical' population of young children with persistent diarrhoea in a low or middle income country; however the wide range of study dates, settings and inclusion criteria does not allow this. Frequencies of different pathogens could feasibly vary according to study setting, particularly in community setting compared with a hospital setting, where the severity of disease is likely to differ. We did not consider it worthwhile to undertake separate analyses for studies carried out in different settings, because the wide range of other differences between studies meant that the results of any such analyses would have been very difficult to interpret.

Despite the limitations of the included studies, and the methods used to combine their results, the findings are useful, as they highlight the range of pathogens that may be associated with persistent diarrhoea, the potential of these pathogens to vary in frequency by time and place, and the uncertainty within populations and individuals that any particular organisms are causal in persistent diarrhoea.

In individual studies comparing children with persistent diarrhoea and without diarrhoea, there were no significant differences between the groups in the prevalence of any individual enteric pathogen, and any differences were small even when all the studies' results were combined. A higher proportion of children with persistent diarrhoea tested positive for any pathogen, but the frequency of detection was also high in children without diarrhoea; across studies that tested for a comprehensive range of organisms, $65 \%$ of children with persistent diarrhoea 
tested positive for at least one pathogen, compared with $43 \%$ of children without diarrhoea. In every study, a proportion of children with persistent diarrhoea did not test positive for any enteric pathogen, although no study included tests for all relevant micro-organisms.

Children with persistent diarrhoea and without diarrhoea carried a wide range of enteric pathogens, including viruses, bacteria and parasites, and the rates of each varied considerably between studies, although there were no apparent differences between WHO regions. The frequency of most pathogens was low, tending to vary in children with persistent diarrhoea from $0 \%$ or $1 \%$ to between $3 \%$ and $20 \%$ between studies. E. coli was an exception, being much more common, detected in between $25 \%$ to $33 \%$ of cases across studies, $6 \%$ to $91 \%$ between studies. This does not take into account the different classes of $E$. coli tested for in different studies.

\section{Conclusion}

There is no evidence that any particular pathogen or type of pathogen is associated with persistent diarrhoea in children under the age of six in low and middle income countries. There is therefore no evidence to justify routine antimicrobial use for children with persistent diarrhoea of unknown cause, in keeping with current guidelines. Even in cases where diagnostic facilities are routinely available, pathogens detected in children with persistent diarrhoea may not be the cause of the illness.

The data currently available on the frequency of different enteric pathogens found in the stools of children with persistent diarrhoea and without diarrhoea is limited in its applicability and generalisability, especially in the range of pathogens being tested for and the locations of the studies. Better quality data, gathered from a range of settings in low and middle income countries throughout the world (including locations where routine microbiological testing is not usually available), and repeated at set time points, could inform health staff in the region of the types of pathogens they should be alert to, and also inform future policy and practice, both locally and globally.

Further good quality studies are needed. The analysis of already available data, for example from hospitals or clinics where routine microbiological testing is used, might also be useful. Studies should ideally run for at least one year, and present data collected over periods of exactly 12 months, or multiples of 12 months, particularly in areas with seasonal climates. Sample sizes should be large enough to give reasonably precise estimates of pathogen frequency, given the wide range of pathogens that may be found, and the low frequency of some of them. Authors should report the study design and microbiological methods in sufficient detail to enable their quality to be assessed. The types of pathogens tested for in these studies should be standardised as far as possible, while remaining flexible to allow the inclusion of new or previously rare or unsuspected pathogens. The classification of enteropathic E. coli should also be standardised if possible, concentrating on clinically useful distinctions between the types.

\section{Abbreviations}

ETEC: Enterotoxigenic E. coli; EIEC: Enteroinvasive E. coli; EPEC: Enteropathogenic E. coli; EaggEC: Enteroaggregative E. coli; EHEC: Enteroheamorrhagic E. coli.

\section{Competing interests}

The authors declare that they have no competing interests.

\section{Authors' contributions}

PG conceived of the study, secured its funding, participated in the design, assisted with the interpretation of data and helped to draft the manuscript. KA wrote the review protocol, inspected the initial search results for potentially relevant publications, selected studies for inclusion, extracted data, undertook the data analysis and drafted the manuscript. RS inspected the initial search results for potentially relevant publications, extracted data, and assisted in the interpretation of data. CAH participated in the design, particularly advising on which pathogens were important and how to handle data on $E$. coli, and assisted in the interpretation of the findings. PG, KA and RS all contributed to and approved the final manuscript. CAH died before the completion of the manuscript. He was a Professor within the Department of Infections and Host Defence, School of Medicine, University of Liverpool. All three living authors read and approved the final manuscript.

\section{Additional material}

\section{Additional file 1 \\ Supplemental tables. \\ Click here for file \\ [http://www.biomedcentral.com/content/supplementary/1471- \\ 2334-9-88-S1.xls]}

\section{Acknowledgements}

Vittoria Lutje devised the search strategy and ran the search. Sarah Donegan advised on statistical methods.

This review was funded by the UK Department for International Develoment (DFID); and with a grant from the World Health Organization

\section{References}

I. Mathers CD, Bernard C, Moesgaard IK, Inoue M, Ma Fat D, Shibuya $\mathrm{S}$, Stein C, Tomijima N, Xu H: Global burden of disease in 2002: data sources, methods and results. In Global programme on evi- 
dence for health policy discussion paper no. 54, (revised 2004) World Health Organization. Geneva; 2003:45.

2. Murray C, Lopez A, eds: Global health statistics: a compendium of incidence, prevalence an mortality estimates for over $\mathbf{2 0 0}$ conditions. Cambridge, MA: Harvard School of Public Health on behalf of the World Health Organization and World Bank; 1996.

3. Lima AAM, Guerrant RL: Persistent diarrhea in children: epidemiology, risk factors, pathophysiology, nutritional impact, and management. Epidemiologic Reviews 1992, 14:222-42.

4. Lima AAM, Moore SR, Barboza MS, Soares AM, Schleupner MA Newman RD, Sears CL, Nataro JP, Fedorko DP, Wuhib T, Schorling JB, Guerrant RL: Persistent diarrhea signals a critical period of increased diarrhea burdens and nutritional shortfalls: a prospective cohort study among children in northeastern Brazil. The Journal of Infectious Diseases 2000, 181:1643-5I.

5. Lumbiganon P, Kosalaraksa P, Loapaiboon M: Survival of children with AIDS: experience in a university hospital in northestern Thailand. Journal of the Medical Association of Thailand 2000, 83(6):652-6.

6. Emodi IJ, Okafor GO: Clinical manifestations of HIV infection in children at Enugu, Nigeria. Journal of Tropical Pediatrics 1998, 44(2):73-6.

7. Lodha R, Upadhyay A, Vishal K, Kabal SK: Clinical profile and natural history of children with HIV infection. The Indian Journal of Pediatrics 2006, 73(3):20I-4.

8. Tumwine JK, Kekitiinwa A, Bakeera-Kitakia S, Ndeezi G, Downing R, Feng $X$, Akiyoshi DE, Tzipori S: Cryptosporidiosis and microsporidiosis in Ugandan chidren with persistent diarrhea with and without concurrent infection with human immunodeficiency virus. American Journal of Tropical Medicine and Hygiene 2005, 73(5): $921-5$

9. Bacqi AH, Sack RB, Black RE, Haider K, Hossain A, Abdul Alim ARM, Yunus M, Chowdhury HR, Siddique AK: Enteropathogens associated with acute and persistent diarrhea in Bangladeshi children < 5 years of age. The Journal of Infectious Diseases 1992, 166:792-6.

10. de Boissieu D, Chaussain M, Badoual J, Raymond J, Dupont C: Smallbowel bacterial overgrowth in children with chronic diarrhoea, abdominal pain, or both. Journal of Pediatrics 2005, I 47(3):410-I.

II. Black RE, Brown KH, Becker S: Malnutrition is a determining factor in diarrheal duraton, but not incidence, among young children in a longitudinal study in rural Bangladesh. American Journal of Clinical Nutrition 1984, 39:87-94.

12. Guarino A, De Marco G: Persistent Diarrhoea, in Pediatric Gastrointestinal Disease BC Decker: USA; 2004:180-193.

13. Handbook IMCl: Integrated Management of Childhood IIIness. WHO and UNICEF; 2006:25.

14. Kimmitt PT, Harwood CR, Barer MR: Toxic gene expression by shiga toxin-producing Escherichia coli: the role of antibiotics and the bacterial SOS response. Emerging Infectious Diseases 2000, 6:458-65.

15. Shahid NS, Sack DA, Rahman M, Alam AN, Rahman N: Risk factors for pesistent diarrhoea. British Medical Journal 1988 297(6655): 1036-8.

16. Mahalanabis D, Alam AN, Rahman N, Hasnat A: Prognostic indicators and risk factors for increased duration of acute diarrhoea and for persistent diarrhea in children. Internationa Journal of Epidemiology I99|, 20(4): I064-72

17. Baqui AH, Sack RB, Black RE, Haider K, Hossain A, Alim ARMA, Yunus M, Chowdhury HR, Siddique AK: Enteropathogens associated with acute and persistent diarrhea in Bangladeshi children $<5$ years of age. The Journal of Infectious Diseases 1992, 166:792-6.

18. Henry FJ, Udoy SU, Wanke CA, Aziz KMA: Epidemiology of persistent diarrhea and etiologic agents in Mirzapur, Bangladesh. Acta Paediatrica 1992:27-31.

19. Bhan MK, Khoshoo V, Sommerfelt H, Raj P, Sazawal SS, Srivastava R: Enteroaggregative Escherichia coli and Salmonella associated with nondysenteric persistent diarrhea. The Pediatric Infectious Disease Journal 1989, 8:499-502.

20. Bhatnagar S, Bhan MK, George C, Gupta U, Kumar R, Bright D, Saini $\mathrm{S}$ : Is small bowel bacterial overgrowth of pathogenic significance in persistent diarrhea? Acta Paediatrica 1992:108-13.
21. Ananthan S, Subramaniam MA: Microbial etiology and assessment of immunological status of children with persistent diarrhoea. The Journal of Communicable Diseases 1995, 27(3): 193-5.

22. Jindal R, Arora R, Bhusan B, Arora S: A study of infective aetiology of chronic diarrhoea in children in Amritsar. Journal of the Indian Medical Association 1995, 93(5): 169-74.

23. Bhandari N, Bahl R, Dua T, Kumar R, Srivastava R: Role of protozoa as risk factors for persistent diarrhea. Indian Journal of Pediatrics 1999, 66:21-6.

24. Mishra OP, Dhawan T, Singla PN, Dixit VK, Arya NC, Nath G: Endoscopic and histopathological evaluation of preschool children with chronic diarrhoea. Journal of Tropical Pediatrics 200I, 47:77-80.

25. Arthur JD, Bodhidatta L, Echeverria P, Phuphaisan S, Sakti P: Diarrheal disease in Cambodian children at a camp in Thailand. American Journal of Epidemiology 1992, 135(5):54I-5I.

26. Ngan PK, Khanh NG, Tuong CV, Quy PP, Anh DN, Thuy HT: Persistent diarrhea in Vietnamese children; a preliminary report. Acta Paediatrica 1992:124-6.

27. Schorling JB, Wanke CA, Schorling SK, McAuliffe JF, de Souza MA Guerrant RL: A prospective study of persistent diarrhea among children in an urban Brazilian slum. American Journal of Epidemiology 1990, 132:144-56.

28. Bartlett AV, Torun B, Morales C, Cano F, Cruz JM: Oral gentamicin is not effective treatment for persistent diarrhea. Acta Paediatrica 1992: 149-54.

29. Guerra-Godinez JC, Larrosa-Haro A, Coello-Ramirez P, Tostado HRA, Rivera-Chavez E, Castillo de Leon YAC, Bojorquez-Ramos , Carmen Ma del, Aguilar-Benavides S: Changing trends in prevalence, morbidity, and lethality in persistent diarrhea in infancy during the last decade in Mexico. Archives of Medical Research 2003, 34:209-I3.

30. Fang GD, Lima AAM, Martins CV, Nataro JP, Guerrant RL: Etiology and epidemiology of persistent diarrhea in northestern Brazil: a hospital-based, prospective, case-control study. Journal of Pediatric Gastroenterology and Nutrition 1995, 2 1: 1 37-44.

31. Amadi B, Kelly P, Mwiya M, Mulwazi E, Sianongo S, Changwe F, Thomson M, Hachungula J, Watuka A, Walker-Smith J, Chintu C: Intestinal and systemic infection, HIV, and mortality in Zambian children with persistent diarrhoea and malnutrition. Journal of Pediatric Gastroenterology and Nutrition 200 I, 32:550-4.

32. Bardhan PK, Albert MJ, Alam NH, Faruque SM, Neogi PKB, Mahalanabis D: Small bowel and fecal microbiology in children suffering from persistent diarrhoea in Bangladesh. Journal of Pediatric Gastroenterology and Nutrition 1998, 26(1):9-15.

33. Chintu C, Luo C, Baboo S, Khumalo-Ngwenya B, Mathewson J, DuPont HL, Zumla A: Intestinal parasites in HIV-seropositive Zambian children with diarrhoea. Journal of Tropical Pediatrics 1995, 41: 149-52.

\section{Pre-publication history}

The pre-publication history for this paper can be accessed here:

\section{http://www.biomedcentral.com/1471-2334/9/88/prepub}

Publish with BioMed Central and every scientist can read your work free of charge

"BioMed Central will be the most significant development for disseminating the results of biomedical research in our lifetime. "

Sir Paul Nurse, Cancer Research UK

Your research papers will be:

- available free of charge to the entire biomedical community

- peer reviewed and published immediately upon acceptance

- cited in PubMed and archived on PubMed Central

- yours - you keep the copyright 